Original research article

\title{
Checklist for nurse anaesthetists in Poland for the safety of patients: a mixed methods design study
}

\author{
Dorota Ozga 1, 2 *, Wioletta Mędrzycka-Dąbrowska ${ }^{2,3}$, Małgorzata Jadczak 2, 4 , Anna Zdun ${ }^{5}$, \\ Aleksandra Gutysz-Wojnicka ${ }^{2,6}$, Paweł Witt ${ }^{7}$ \\ ${ }^{1}$ Institute of Health Sciences, College of Medical Sciences of the University of Rzeszow, Poland, Rzeszow, Poland \\ ${ }^{2}$ Polish Association of Anaesthesiology and Intensive Care Nurses, Poznań, Poland \\ ${ }^{3}$ Medical University in Gdańsk, Department of Anaesthesiology Nursing and Intensive Care, Gdańsk, Poland \\ ${ }^{4}$ Clinical Children's Hospital of Medical University of Warsaw, University Clinical Center, Clinical Department of Neurosurgery with Motor System \\ Traumatology Unit, Warsaw, Poland \\ ${ }^{5}$ Independent Public Clinical Hospital of the prof. W. Orlowski, Hospital Postgraduate Medical Education Center, Clinic of Anaesthesiology and Intensive \\ Therapy, Warsaw, Poland \\ ${ }^{6}$ University of Warmia and Mazury in Olsztyn, Faculty of Medical Sciences, Department of Nursing, Olsztyn, Poland \\ ${ }^{7}$ Independent Public Children's Clinical Hospital in Warsaw, Department of Anaesthesiology and Intensive Therapy, Department of Anaesthesiology, \\ Intensive Therapy and Post-operative care, Warsaw, Poland
}

\begin{abstract}
The aim of this study is the further development and verification of "The Check-List for Nurse Anaesthetists" (CLNA). A mixed method study design was applied in order to do so. A focus group consisting of 13 nurses - with a long-standing professional experience in anaesthesiology and intensive care nursing - participated in the first stage of testing. They developed a check-list for nurse anaesthetists. Then, the group attempted to validate and standardise the developed tool. The check-list made it possible to gather information on the procedures performed by nurse anaesthetists which were grouped in six sections. In total, 130 check-lists were validated during the second stage of testing. The Check-List for Nurse Anaesthetists increases the safety of the nursing staff and patients; it helps to maintain a safe working environment, increase responsibility for safe working conditions and awareness of the responsibility among nurse anaesthetists, as well as collect information on the causes of adverse events in anaesthesiology nursing, record them and modify practice accordingly. According to the Working Group of the Polish Association of Anaesthesiology and Intensive Care Nurses, The CheckList for Nurse Anaesthetists should be included in the mandatory or minimum list of additional internal patient documentation.
\end{abstract}

Keywords: Anaesthetist; Check-List; Nurse; Nursing Documentation; Patient Safety; Validation Studies

\section{Introduction}

The level of care and the quality of the healthcare system in general determines the safety of patients using the healthcare services. These can be assessed through an accurate analysis of causes, through monitoring and reporting of adverse events and medical errors. Taking into consideration the ergonomic aspects of the events makes it possible to limit their number and contain the damage. An example of a proper preventive measure against medical errors is the introduction of appropriate documentation for the medical personnel. The Regulation of the Minister of Health (MH) of 12 December 2018 on the organisational standard of healthcare in the field of anaesthesiology and intensive care in Poland defines the obligations connected with completing the anaesthesia record card and the organisation of anaesthesiological work. Article 9 of the above Regulation states, inter alia, that an anaesthetist may simultaneously anaesthetise only one patient, and a nurse anaesthetist cooperates with an anaesthetist during anaesthesia (Dziennik Ustaw, 2018). The physician administering anaesthesia should be close to the patient for the duration of the anaesthesia. According to article 9 (12) of the above Regulation, the physician administering anaesthesia should complete the anaesthesia record card (Dziennik Ustaw, 2018). This legal act does not specify the type or form of medical record in which the nurse anaesthetists tasked with the anaesthesiological care are obliged and authorised to record and document their activities. At the same time, according to Polish law, a nurse cannot replace a physician in performing activities which, under the applicable laws, are their sole responsibility (PTPAiIO, 2012). The role of the nurse anaesthetist during anaesthesiological care is defined as a collaboration with the physician administering anaesthesia. This situation gives rise to some doubts as to whether the lack of documentation concerning the activities performed by nurse anaesthetists could

\footnotetext{
* Author for correspondence: Dorota Ozga, Institute of Health Sciences, College of Medical Sciences of the University of Rzeszow, St. Warzywna 1A, 35-310 Rzeszow, Poland; e-mail: gdozga@poczta.fm http://doi.org/10.32725/kont.2020.006

Submitted: 2019-08-07 • Accepted: 2020-01-06 • Prepublished online: 2020-02-10 
lead to professional liability issues in the event of a claim. In response to these concerns, in February 2012 the Working Group (WG) of the Polish Association of Anaesthesiology and Intensive Care Nurses (PTPAiIO) developed "The Check-list for Nurse Anaesthetists (CLNA)", and recommended its use for individual patient documentation (PTPAiIO, 2012). The aim of this study is the further development and verification of "The Check-List for Nurse Anaesthetists (CLNA)".

\section{Materials and methods}

A sequential mixed methods design (qualitative and quantitative research) was used for the purposes of this project (Creswell, 2003) as illustrated in Fig. 1. A mixed methods design answers both "what?" and "how?".

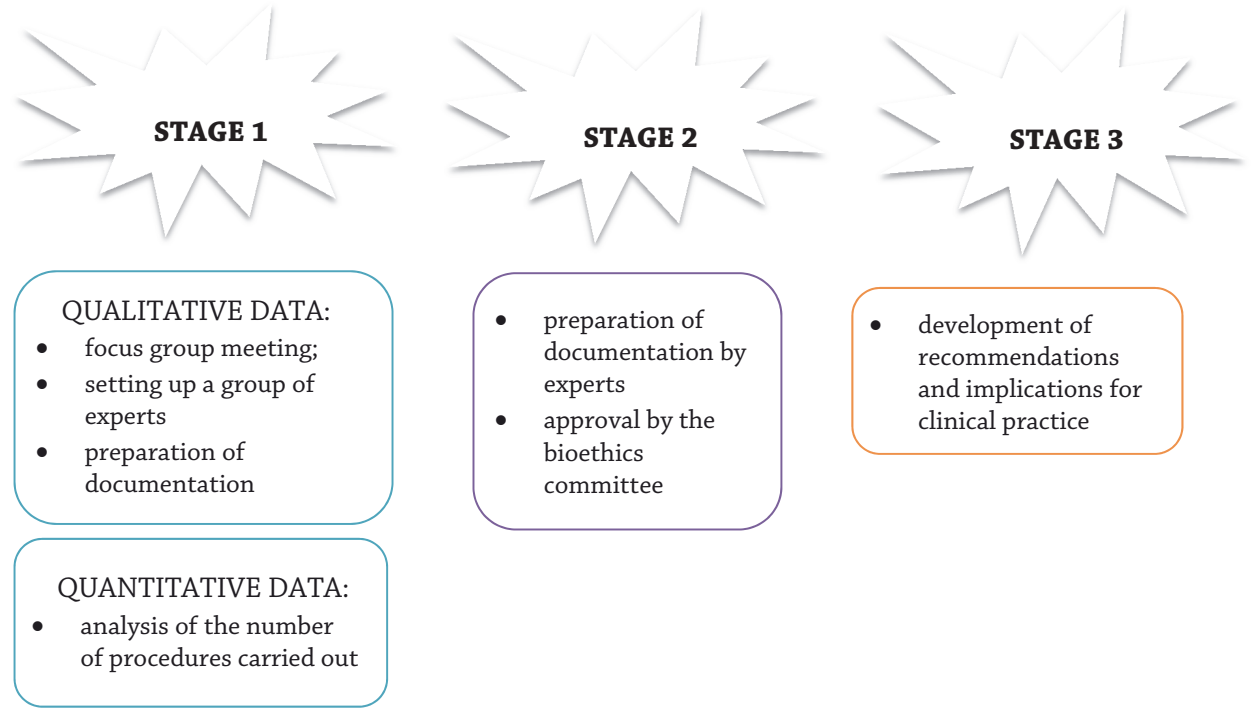

Fig. 1. Diagram of mixed method study design

The expert group consisted of 13 nurses with a long-standing professional experience in anaesthesiology and intensive care nursing, an average mean score of $19.3, \mathrm{SD}=8.5$ years of professional experience in working at the Anaesthesiology and Intensive Care Unit (A\&ICU), Min-7, and Max-30. One of the hospitals in which the regional branch of the PTPAiIO operates was selected at random to validate the tool. The study was conducted at the Anaesthesiology and Intensive Care Unit in the period between 1 and 30 June 2013.

In the second stage of the research, the check-list was completed randomly by nurse anaesthetists during surgery. After collecting the research material, a statistical analysis was performed. The average age of the patients amounted to a mean score of $48.3, S D=24.0$ years. The youngest examined person was 4 months old and the oldest was 93 years old. The experts compiled 55 groups of questions that referred to specific activities performed by nurses tasked with anaesthesiological care, ranging from a patient's admission to the operating theatre to transferring the patient back to the ward, which should be included in "The Check-List for Nurse Anaesthetists". These questions were grouped in such a way as to reflect the order of nursing activities during anaesthesia and were divided into: preparation of the operating theatre, preparation of the anaesthesia (according to standards), preparation of the patient, and the course of the anaesthesia, patient status, and cleaning of the anaesthetic environment.

Stage 1, Focus Group Verification. A focus group was used in the study - in which the experience, knowledge and expert opinions in the specific field are used to solve the research problem. Experts from across Poland, affiliated in the regional branches of the PTPAiIO, were appointed as experts in the WG. The expert group consisted of 13 nurses specialising in anaesthesiology and intensive care, two of them were court-appointed experts in this field; all 13 nurses had experience in providing direct patient care in the ICU, six had experience working as academic teachers in medical departments in Poland and five as head nurses at the A\&ICU. The group met on 23 September 2011. During the first stage of the study, the research problem, namely "The lack of documentation for a nurse anaesthetist during anaesthesiological care", was presented to experts. Brainstorming was used to find an answer. After the experts submitted their proposals for a solution, the suggested solutions were classified. The next step in the study included an anonymous questionnaire, in which the experts were asked to prepare documentation proposals. When the model documentation proposals were collected, the WG met on 3-5 September 2012 and 22-24 April 2013. During the last WG meeting, the final version of "The Check-List for Nurse Anaesthetists" was prepared. The group then attempted to validate and standardise the developed tool. The documentation prepared shows that all activities were carried out in accordance with the legal requirements. The template of the record is available free of charge on the PTPAiIO website / Working Group tab. There is a register of hospitals reporting a willingness to use the template in their facility. Until July 2017, 15 hospitals in Poland used it in their anaesthesia and intensive care units. Every hospital in Poland can download it free of charge and modify it to make it suitable for their units. The analysis was conducted using the Polish version of the Statistica 13.3 statistical package. The statistical analysis included the basic descriptive measures adjusted to variables, i.e. average, standard deviation, median, quartile distribution, upper and lower quartiles, and minimum and maximum values. The following rules were adopted: $p<0.05$ indicated statistically significant dependence (this was marked with ${ }^{*}$ ); $p<0.01$ indicated a highly significant relationship (this was marked 
with $\left.{ }^{* *}\right) ; p<0.001$ indicated a very highly statistically significant relationship (this was marked with ${ }^{* * *}$ ). The reliability of the card was based on the Cronbach's alpha coefficient, where the value of $0.6-1.0$ was assumed as a value confirming the reliability of the scale.

\section{Results}

As part of the quantitative research, the CLNA was used to gather information on the activities carried out in anaesthesiological care, which were later grouped into six sections. (Table 1).

In each section, the activities of nurse anaesthetists during anaesthesiological care were enumerated and assigned a value of 1 or 2 points (for activities requiring more work). Each section had a variable distinguished as the general indicator, including the sum of points from the individual activities in the section and a variable as a general normalised indicator from 0 to 100 for comparative purposes between sections, where 82 points represents 100. The general (normalised) index allows the specification of the number of activities (level of activity) performed during a single surgery with respect to all possible activities in a given section (Table 2 ).

The total score in the activities of Section 1 - Preparation of Anaesthetic Environment - ranged from 0 to 12 points. The mean score obtained in the study group was $7, \mathrm{SD}=0.21$ points with a median of 7 points. For standardised results, the average level of activity in Preparation of Anaesthetic Environment amounted to a mean score of $58.3, S D=0.21$ with a median of 58.3. The total score in Characteristics of the Surgery ranged from 0 to 6 points. The mean score obtained in the study group was $0.78, S D=0.21$ points with a median of 1 point. For standardised results, the average level of activity in Type of Surgery and Anaesthetist's Exposure amounted to a mean score of 35.54, SD $=0.71$ with a median of 20. Subsequently, the total score in Preparation of the Patient ranged from 0 to 18 points. The mean score obtained in the study group was $8.1, \mathrm{SD}=2.01$ points with a median of 9 points. For standardised results, the average level of activity in Preparation of the Patient amounted to a mean score of 47.27 , SD $=11.18$ with a median of 50 . The total score in The Course of Anaesthesia ranged from 0 to 32 points. The mean score obtained in the study group was $12.21, S D=6.18$ points with a median of 10 points. For normalised results, the average level of activity in The Course of Anaesthesia amounted to a mean score of $38.15, \mathrm{SD}=19.31$ with a median of 31.25 . The total score in Transfer of the Patient after Surgery ranged from 0 to 11 points. The mean score obtained in the study group was $3.30, \mathrm{SD}=1.56$ points with a median of 3 points. For normalised results, the average level of activity in The Course of the Anaesthesia was 30, SD $=14.21$ with a median of 27.27. The score in the section Cleaning of the Anaesthetic Environment ranged from 0 to 3 points. The mean score obtained in the study group was $2.63, \mathrm{SD}=0.94$ points with a median of 3 points. For normalised results, the average level of activity in Cleaning of the Anaesthetic Environment amounted to a mean score of $87.69, \mathrm{SD}=31.37$ with a median of 100 . A general index of a nurse's activity in anaesthesiological care was calculated. The mean score obtained in the study group was $35.42, \mathrm{SD}=10.03$ points with a median of 33 points. For normalised results, the average level of activity of a nurse anaesthetist amounted to a mean score of $42.20, S D=12.23$ with a median of 40.24 (Table 3).

\section{Table 1. The Check-list for nurse anaesthetists}

Section 1 - Preparation of anaesthetic environment

(by standards); total score: $\mathbf{0 - 1 2}$ points

1. Control of anaesthetic machine

2. Preparation of monitoring equipment

3. Preparation of intubation kit

4. Preparation for peripheral venous catheter insertion

5. Preparation for central catheter insertion

6. Preparation for arterial catheter insertion

7. Preparation of anaesthesia

8. Preparation of kits for conduction anaesthesia - epidural

9. Preparation of kits for conduction anaesthesia - subarachnoid

10. Preparation of kits for conduction anaesthesia - nerve block

11. Control of the resuscitation kit, medication and accessory equipment

12. Patient warming system

\section{Section 2 - Characteristics of the surgery;}

total score: 1-6 points

1. Type of surgery ( 1 - scheduled; 2 - emergency)

2. Exposure to hepatitis $C$

3. Exposure to HIV

4. Exposure to injury

5. Exposure to haemorrhage

Section 3 - Preparation of the patient; total score: 0-18 points

1. Identification of a patient

2. Confirming the kind of surgery

3. Identification bracelet

4. Written consent to surgery

5. Written consent to anaesthesia

6. Initial assessment of the patient - time from last meal

7. Initial assessment of the patient - problems concerning communication

8. Initial assessment of the patient - problems concerning mobility/ pain

9. Initial assessment of the patient - visible skin damage

10. Initial assessment of the patient - infectious disease

11. Initial assessment of the patient - allergies

12. Initial assessment of the patient - consciousness - oriented

13. Initial assessment of the patient - consciousness - confused

14. Initial assessment of the patient - consciousness - unconscious

15. Initial assessment of the patient - consciousness - drowsy

16. Prosthesis

17. Blood and fluids warming system

18. Disinfectant

Section 4 - The Course of anaesthesia; total score: 0-32 points

1. Assist (by standards) - Total score -8 points

2. Performed activities and procedures - Total score -11 points

3. Monitoring ( 0 - none, 1 - basic, 2 - advanced) - Total score 2 points

4. Nursing procedures - Total score -7 points

5. The course of anaesthesia ( 0 - none, 1 - uneventful, 2 - adverse events) - Total score -2 points

6. Jewellery - Total score -1 points

7. Other - Total score -1 points

Section $\mathbf{5}$ - Transfer of the patient after surgery;
total score: $\mathbf{0 - 1 1}$ points
1. Infusion pumps
2. Drainage
3. Medical documentation
4. Patient's condition - unconscious
5. Patient's condition - conscious
6. Patient's condition - drowsy
7. Patient's condition - agitated
8. Patient's condition - intubated
9. Patient's condition - ventilated
10. Operative pain (0 - none, 1 - pain on transfer, 2 - severe pain)
Section $\mathbf{6}$ - Cleaning of the anaesthetic environment;
total score: $\mathbf{0 - 3}$ points
1. Disinfection of the equipment
2. Disinfection of the position
3. Supplementing shortages




\begin{tabular}{|c|c|c|c|c|c|c|c|c|c|c|}
\hline & $N$ & $x$ & $\mathrm{Me}$ & Min & Max & Q1 & Q3 & SD & Skewness & Kurtosis \\
\hline \multicolumn{11}{|c|}{ Section 1 - Preparation of anaesthetic environment } \\
\hline General indices & 130 & 7.0 & 7.0 & 4.0 & 10.0 & 6.0 & 8.0 & 1.4 & 0.1 & -0.97 \\
\hline General indices normalised & 130 & 58.3 & 58.3 & 33.3 & 83.3 & 50.0 & 66.7 & 12.1 & 0.1 & -0.97 \\
\hline \multicolumn{11}{|c|}{ Section 2 - Characteristics of the surgery } \\
\hline General indices & 130 & 1.78 & 1.00 & 1.00 & 4.00 & 1.00 & 3.00 & 0.98 & 0.71 & -1.07 \\
\hline General indices normalised & 130 & 35.54 & 20.00 & 20.00 & 80.00 & 20.00 & 60.00 & 19.65 & 0.71 & -1.07 \\
\hline \multicolumn{11}{|c|}{ Section 3 - Preparation of the patient } \\
\hline General indices & 130 & 8.51 & 9.00 & 0 & 14.00 & 8.00 & 9.00 & 2.01 & -0.64 & 4.74 \\
\hline General indices normalised & 130 & 47.27 & 50.00 & 0 & 77.78 & 44.44 & 50.00 & 11.18 & -0.64 & 4.74 \\
\hline \multicolumn{11}{|c|}{ Section 4 - The Course of anaesthesia } \\
\hline General indices & 130 & 12.21 & 10.00 & 0 & 23.00 & 8.00 & 18.00 & 6.18 & 0.12 & -1.1 \\
\hline General indices normalised & 130 & 38.15 & 31.25 & 0 & 71.88 & 25.00 & 56.25 & 19.31 & 0.12 & -1.1 \\
\hline \multicolumn{11}{|c|}{ Section 5 - Transfer of the patient after surgery } \\
\hline General indices & 130 & 3.30 & 3.00 & 0 & 7.00 & 2.00 & 5.00 & 1.56 & -0.03 & -0.34 \\
\hline General indices normalised & 130 & 30.00 & 27.27 & 0 & 63.64 & 18.18 & 45.45 & 14.21 & -0.03 & -0.34 \\
\hline \multicolumn{11}{|c|}{ Section 6 - Cleaning of the anaesthetic environment } \\
\hline General indices & 130 & 2.63 & 3.00 & 0 & 3.00 & 3.00 & 3.00 & 0.94 & -2.31 & 3.62 \\
\hline General indices normalised & 130 & 87.69 & 100.00 & 0 & 100.00 & 100.00 & 100.00 & 31.37 & -2.31 & 3.62 \\
\hline
\end{tabular}

Table 3. Characteristics of descriptive statistics of the indices of the anaesthetic nurse activity in the anaesthetic environment in the study group, for the whole scale

\begin{tabular}{|c|c|c|c|c|c|c|c|c|c|c|}
\hline $\begin{array}{l}\text { Index of activity level of anaesthetic nurse } \\
\text { in the anaesthetic environment }\end{array}$ & $N$ & $x$ & $\mathrm{Me}$ & Min & Max & Q1 & Q3 & SD & Skewness & Kurtosis \\
\hline General index & 130 & 35.42 & 33.00 & 7 & 54.00 & 28.00 & 45.00 & 10.03 & -0.14 & -0.43 \\
\hline General index normalised & 130 & 43.20 & 40.24 & 9 & 65.85 & 34.15 & 54.88 & 12.23 & -0.14 & -0.43 \\
\hline
\end{tabular}

The reliability of the questionnaire for a nurse anaesthetist was analysed. In the statistical analysis, attention was paid to the calculation of psychometric values (Cronbach's alpha coefficient) being 0.90 for the whole questionnaire, which indi-cates its very high reliability (Table 4, Annex 1 ).

Table 4. Cronbach's alpha coefficient for the Polish version of the questionnaire

\begin{tabular}{lcccc} 
Cronbach's alpha & Number of positions & SD & $N$ \\
\hline 0.598 & 11 & 35.42 & 10.03 & 130 \\
\hline
\end{tabular}

\section{Discussion}

Medical documentation has a number of functions in healthcare. It supports clinical decision-making related to planning and nursing care, supports the patient transfer between medical establishments, and provides clarity in terms of the quality and continuity of patient care (Alexander et al., 2011; Braaf et al., 2011; Phipps et al., 2018; WHO, 2018). International accreditation organisations specify that documenting the provision of healthcare services to patients must support clinical decision-making and enhance the continuity of patient care; documentation is a condition for the safety of patients and for ensuring quality in nursing (Braaf et al., 2011; Phipps et al., 2018; WHO, 2018). Furthermore, it is the basis for internationally recognised quality assurance methods, such as the European Commission requirement stating that documenta- tion, quality control, and quality development and evaluation are an integral element of medical services (Braaf et al., 2011; Phipps et al., 2018; WHO, 2018). Therefore, nursing documentation plays a key role in improving the quality of patient care and clinical procedures (Braaf et al., 2011; Chappy, 2006). In a number of research studies and practical publications, few global sets of requirements for recording specialised perioperative anaesthesiological nursing care were found (Chappy, 2006; Junttila et al., 2002), although there is a general consensus that documenting perioperative nursing care is of key importance for the safety of patients and the continuity of nursing care within the operating theatre (Chappy, 2006; Wilbanks, 2013). International documents show significant differences in documentation practice in the field of perioperative nursing. A multicentre quality analysis (Junttila et al., 2002) and literature reviews (Braaf et al., 2011; Wilbanks, 2013) provide incomplete knowledge, data and understanding 
of the perioperative nursing documentation practice, suggesting that the data are random and of low quality, which is a source of serious health risks for patients. The research shows that documentation-related practice differs in particular wards and hospitals; there are organisational and individual differences in the content, tools and levels of nurses' involvement in record-keeping (Braaf et al., 2011; Wilbanks, 2013).

Maintaining medical records is the duty of every medical facility, but also every physician, nurse and midwife who runs a practice. The obligation to keep medical records is to ensure the possibility to control and verify whether the healthcare services were correctly performed. Proper medical records are closely connected with the legal responsibility of nurses (Rudnik, 2015). In the event that the patient or their family files a claim, such medical records will be the basis for the authorities conducting the investigation to determine whether any legal or professional ethics provisions have been violated. Medical records are often the only evidence in such cases and, depending on how well they were kept, they can contribute to dismissing or confirming legal charges. Medical records can be a tool for the defence of a nurse or a basis for civil, criminal, disciplinary or professional liability (Rudnik, 2015).

\section{Analysis of the applicable legal regulations regarding anaesthesiological nursing documentation in Poland}

The Regulation of the Polish Minister of Health of 9 May 2015 on the types, scope and templates of medical records and their processing (Dziennik Ustaw, 2015, item 2069) regulates in detail the principles of keeping medical records and assigning specified tasks to entities participating in the implementation of health services (Dziennik Ustaw, 2015). This Regulation specifies, among others, who (physician, nurse or midwife) is legally obliged and who is entitled to maintain certain medical records (Dziennik Ustaw, 2015). Where the Regulation of the Minister of Health assigns the right to make entries in a document to a given person, then no one else has such authority, and if another person makes such a record despite this Regulation, it is in breach of the law. It should also be noted that the rules governing medical records, set out in a high-level legal act, i.e. a regulation subject to an act, cannot be regulated by lower-level acts, such as ordinances or internal regulations adopted by the management bodies of medical entities.

In the event of providing medical services related to anaesthesia for an operative procedure, the Regulation of the Polish Minister of Health of 9 May 2015 on the types, scope and templates of medical records and their processing imposes the obligation to maintain internal individual records - the medical history accompanied by additional documents including, but not limited to, the anaesthesia record card, the surgical operation note and the perioperative control card.

According to the Regulation of the Minister of Health, entries in the perioperative control card are made by its coordinator, who is the person defined in the organisational regulation of the medical entity. The perioperative control card contains identification of the patient and grouped information on the necessary procedures: before administering anaesthesia to the patient, before the incision and before the patient leaves the operating theatre (Dziennik Ustaw, 2015). The perioperative control card, in the section on procedures performed before the patient's anaesthesia, includes, in particular, the name of the patient, the date of the surgery, the name of the organisational unit in which the patient was staying, the number in the main book of admissions and discharges, the type of surgery, the operative site, the operating procedure, the consent for surgery, the type of anaesthesia, information on marking the operative site, confirmation of the anaesthesia safety assessment, confirmation of the basic monitoring, allergy information, information on the anticipated difficulties in maintaining airway patency, and information on the risk of bleeding $>500 \mathrm{ml}$ in adults or $>7 \mathrm{ml} / \mathrm{kg}$ of body weight in children (Mellin-Olsen et al., 2010).

The perioperative control card, in the section on procedures performed before the incision, includes in particular the confirmation by the members of the surgical team that they know each other's identity and function in the team, information that all members of the surgical team were introduced to one another if they do not know one another, information that the surgeon, anaesthesiologist, nurse anaesthetist and operating nurse confirmed the patient's identity, the surgical site, the operating procedure, and the correct patient position. Further requirements include a confirmation from the operating nurse of the correct set of tools, information on possible deviations from the planned operating procedure, type or technique of surgery, prolongation of surgery time, change of anaesthesia, expected loss of blood, supplementation or change in the kit of tools by the surgeon, the anaesthetist or the operating nurse, information on the use and documentation of perioperative antibiotics up to 60 minutes prior to the surgery, on the use of anticoagulant prevention, and on the preparation of imaging results (Dziennik Ustaw, 2015). The perioperative control card, in the section on the procedures performed prior to transferring the patient out of the operating theatre, includes in particular confirmation by the surgical team of the name of the procedure performed, confirmation by the operating nurse of the compliance of the number of tools and materials used, information on the samples taken, on the occurrence of complications in surgery, on problems with equipment or technical issues, information on the possible postoperative problems provided by the surgeon and anaesthetist, on the postoperative orders by the surgeon and anaesthetist and on documenting the patient's condition prior to their transfer from the operating block to the postoperative ward or postoperative room. The perioperative control card is signed by the card coordinator (Dziennik Ustaw, 2015). On behalf of the Polish Association of Anaesthesiology and Intensive Care Nurses, we fully support the promotion of safe perioperative care, the goals of which are described in detail in the Helsinki Declaration on Patient Safety in Anaesthesiology (Mellin-Olsen et al., 2010; Petrini et al., 2010; Whitaker et al., 2011).

Patients have the right to expect safety and protection when they are provided with healthcare services, and anaesthesia plays a key role in improving perioperative patient safety. Therefore, we fully accept and declare our willingness to adhere to the International Standards for Safe Anaesthesia of the World Federation of Anaesthesia Societies. Patients need to be educated and should be given an opportunity to provide feedback to facilitate further improvements in anaesthetic care. Entities responsible for financing the healthcare system have the right to expect safe services in perioperative care for which they are required to provide adequate financial resources. Education plays an important role in improving patient safety, so we fully support the development, dissemination and implementation of patient safety training (AORN, 2020; MellinOlsen and Staender, 2014; Schleppers et al., 2011; Steander et al., 2013). Human factors are an important element in the process of patient care, so to increase safety we will be responsible for promoting the work standards of nurse anaesthetists. The successes of modern anaesthetics derive from improved technology, pharmacology, training and education, improved systems, focus on human effectiveness, and the standardisa- 
tion and development of core information. All these aspects are crucial and relevant for widely accepted, state-of-the-art general practice, but they also refer to nursing care (Horváth et al., 2012; Staender, 2015).

Nurse anaesthetists encounter a number of technical and practical issues related to nursing documentation (Braaf et al., 2011; Sorensen et al., 2014). A template documentation tool must be adjusted to and compliant with the applicable clinical practice (Yontz et al., 2015). Perioperative documentation is made in parallel with the nursing practice; this creates a time-related challenge, as the documentation tool must be compliant with the relevant practice (Braaf et al., 2011; Sorensen et al., 2014; Tiusanen et al., 2010; Yontz et al., 2015). Perioperative nurses deal with patient safety, pointing to the relationship between proper medical documentation and the safety of patients (Braaf et al., 2011; International Federation of Perioperative Nurses, 2014; Junttila et al., 2000; Park et al., 2007). In the perioperative practice, emphasis is placed on the safety of patients, preventing their injuries and ensuring the coherence of the patient pathway in general (Braaf et al., 2011; Park et al., 2007; Sorensen et al., 2014).

\section{Limitations of this study}

This study has certain limitations. The studied lay-person respondents and healthcare workers were from south-east Poland (Podkarpackie). Research in a more diverse group of patients is recommended.

\section{Conclusions}

The introduction of the record card would allow an increase in patient safety, a safe working environment, greater respon- sibility for safe working conditions, increased awareness of the responsibility of a nurse anaesthetist, information on the causes of adverse events in anaesthesiology nursing, their recording and modification of practice. According to the Working Group of the Polish Association of Anaesthesiology and Intensive Care Nurses, "The Check-List for Nurse Anaesthetists" should be included in the mandatory or minimum additional internal patient documentation.

\section{Authors' contributions}

DO, WM-D, AG-W, and PW drafted the initial manuscript; AZ, $\mathrm{JM}$, and DO provided expertise. MJ conceived the concept underlying the manuscript and is the senior author of the paper. All authors were involved in writing and editing the manuscript, including the table, and read and approved the final version.

\section{Ethical aspects and conflict of interests}

This study was conducted according to the guidelines laid down in the Declaration of Helsinki, and all procedures involving human subjects were approved by the Bioethics Committee, Poland (No. 1239, 18 December 2008). A written informed consent was obtained from each subject. The authors have no conflict of interests to declare.

\section{Acknowledgments}

We would like to thank Małgorzata Zadubiec for her valuable comments in creating a professional translation.

\title{
Kontrolní seznam pro zajištění bezpečnosti pacientů určený pro anesteziologické sestry v Polsku: smíšená (kvalitativní a kvantitativní) studie
}

\begin{abstract}
Souhrn
Cílem této studie je prověření a další rozvoj „Kontrolního seznamu pro anesteziologické sestry“ (CLNA). Pro tento účel byla použita kvalitativně-kvantitativní studie. První fáze studie se zúčastnilo technikou focus group 13 zdravotních sester s dlouhodobými pracovními zkušenostmi v oblasti anesteziologie a intenzivní péče. Tyto zdravotní sestry vyvinuly kontrolní seznam pro anesteziologické sestry. Posléze se tato skupina sester pokusila tento kontrolní seznam prověřit a standardizovat. Kontrolní seznam umožnil sběr informací o zákrocích provedených anesteziologickými sestrami. Tyto zákroky byly rozděleny do šesti skupin. Během druhé fáze testování bylo prověřeno celkem 130 kontrolních seznamů. Kontrolní seznam CLNA zvyšuje bezpečnost jak zdravotních sester, tak pacientů; pomáhá udržovat bezpečné pracovní prostředí, určit, kdo zodpovídá za bezpečné pracovní podmínky a zvýšit pocit zodpovědnosti mezi anesteziologickými sestrami. Tento kontrolní seznam také pomáhá sbírat a zaznamenávat informace o př́ičinách negativních událostí v anesteziologickém ošetřovatelství, aby následně mohly být příslušné postupy upraveny. Podle „Pracovní skupiny polské asociace anesteziologických sester a zdravotních sester v oboru intenzivní péče“ by měl být v budoucnu kontrolní seznam CLNA povinnou součástí pacientovy interní zdravotní dokumentace.
\end{abstract}

Klíčová slova: anesteziolog; bezpečnost pacientů; kontrolní seznam; validační studie; zdravotní sestra; zdravotnická dokumentace

\section{References}

1. Alexander EL, Rothrock JC, Mcewen DR (2011). Alexander's care of the patient in surgery. 14th. ed. St. Louis, MO: Mosby/ Elsevier.

2. AORN Syntegrity (C 2020). Perioperative Nursing Data Set. [online] [cit. 2019-01-30]. Available from: https://www.aorn. org/syntegrity
3. Braaf S, Manias E, Riley R (2011). The role of documents and documentation in communication failure across the perioperative pathway. A literature review. Int J Nurs Stud 48(8): 1024-1038. DOI: 10.1016/j.ijnurstu.2011.05.009.

4. Chappy S (2006). Perioperative patient safety: a multisite qualitative analysis. AORN J 83(4): 871-874, 877-888, 891-897. DOI: 10.1016/s0001-2092(06)60008-2.

5. Creswell JW (2003). Research design: qualitative, quantitative and mixed methods approaches. Thousand Oaks, CA: Sage Publications: USA. DOI: 10.1016/j.jcjq.2017.12.006. 
6. Dziennik Ustaw (2015). Regulation of the Minister of Health on the types, scope and templates of medical records and their processing. [online] [cit. 2019-08-06]. Available from: http:// dziennikustaw.gov.pl/du/2015/2069

7. Dziennik Ustaw (2018). Regulation of the Minister of Health on the organisational standard of healthcare in the field of anaesthesiology and intensive care. [online] [cit. 2019-08-06] Available from: http://prawo.sejm.gov.pl/isap.nsf/download. xsp/WDU20180002381/O/D20182381.pdf

8. Horváth A, Reusz G, Gál J, Csomós A (2012). Improving patient safety in perioperative care for major surgeries. Orv Hetil 153(37): 1447-1455. DOI: 10.1556/OH.2012.29446.

9. International Federation of Perioperative Nurses (2014). Guideline for developing standards, patient safety - our primary goal. [online] [cit. 2019-01-13]. Available from: https://inmo.ie/ tempDocs/EORNA\%20IFPN\%20Patient\%20Safety.pdf

10. Junttilla K, Lauri S, Salantera S, Hupli M (2002). Initial validation of the perioperative nursing data set in Finland. Nurs Diagn 13(2): 41-52. DOI: 10.1111/j.1744-618X.2002. tb00165.x.

11. Junttila K, Salantera S, Hupli M (2000). Perioperative documentation in Finland. AORN J 72(5): 862-866, 868, 870-873. DOI: 10.1016/S0001-2092(06)62018-8.

12. Mellin-Olsen J, Staender S (2014). The Helsinki declaration on patient safety in anaesthesiology: the past, present and future. Curr Opin Anaesthesiol 27(6): 630-634. DOI: 10.1097/ ACO.0000000000000131.

13. Mellin-Olsen J, Staender S, Whitaker DK, Smith AF (2010). The Helsinki Declaration on Patient Safety in Anaesthesiology. Eur J Anaesthesiol 27(7): 592-597. DOI: 10.1097/ EJA.0b013e32833b1adf.

14. Park HA, Lee HJ, Yoon $\mathrm{K}$ (2007). The perioperative nursing data set in Korean: translation, validation, and testing. AORN J 86(3): 424-445. DOI: 10.1016/j.aorn.2007.04.001.

15. Petrini F, Solca M, De Robertis E, Peduto VA, Pasetto A, Conti G, et al. (2010). The Helsinki Declaration on Patient Safety in Anaesthesiology: a way forward with the European Board and the European Society of Anaesthesiology. Minerva Anestesiol 76(11): 971-977.

16. Phipps A, Paradis M, Peterson K, Jensen J, Nielsen K, Hall M, et al. (2018). Reducing Serious Safety Events and Priority Hospital-Acquired Conditions in a Pediatric Hospital with the Implementation of a Patient Safety Program. Jt Comm J Qual Saf 44(6): 334-340.
17. PTPAiIO (2012). Recommendation of the working group on practices in anaesthesia and intensive care nursing PTPAiIO concerning the documentation of an anaesthesiologist. [online] [cit. 2019-08-06]. Available from: http://www.ptpaio.pl/ dokumenty/5.pdf

18. Rudnik K (2015). Odpowiedzialność prawna i dokumentacja medyczna pielęgniarki anestezjologicznej (Legal responsibility and medical documentation of nurse anaesthetists).

Pieleggniarstwo w Anestezjologii i Intensywnej Opiece 1(3):145148. DOI: $10.15374 /$ PwAiIO2015008.

19. Schleppers A, Prien T, Van Aken H (2011). Helsinki Declaration on patient safety in anaesthesiology: Putting words into practice - Experience in Germany. Best Pract Res Clin Anaesthesiol 25(2): 291-304. DOI: 10.1016/j.bpa.2011.02.011.

20. Sorensen EE, Olsen IO, Tewes M, Uhrenfeldt L (2014). Perioperative nursing in public university hospitals: an ethnography. BMC Nurs 13(1): 1-9. DOI: 10.1186/s12912-0140045-7.

21. Staender S (2015). Safety-II and resilience: the way ahead in patient safety in anaesthesiology. Curr Opin Anaesthesiol 28(6): 735-739. DOI: 10.1097/ACO.0000000000000252.

22. Staender S, Smith A, Brattebø G, Whitaker D (2013). Three years after the launch of the Helsinki Declaration on patient safety in anaesthesiology: the history, the progress and quite a few challenges for the future. Eur J Anaesthesiol 30(11): 651-654.

23. Tiusanen TS, Junttila K, Leinonen T, Salantera S (2010). The validation of AORN recommended practices in Finnish perioperative nursing documentation. AORN J 91(2): 236-247. DOI: 10.1016/j.aorn.2009.06.027.

24. Whitaker DK, Brattebø G, Smith AF, Staender SE (2011). The Helsinki Declaration on Patient Safety in Anaesthesiology: putting words into practice. Best Pract Res Clin Anaesthesiol 25(2): 277-290. DOI: 10.1016/j.bpa.2011.02.001.

25. WHO (2018). Patient safety. [online] [cit. 2019-01-02]. Available from: https://www.who.int/patientsafety/en/

26. Wilbanks BA (2013). An integrative literature review of contextual factors in perioperative information management systems. Comput Inform Nurs 31(12): 622-628. DOI: 10.1097/ CIN.0000000000000007.

27. Yontz LS, Zinn JL, Schumacher EJ (2015). Perioperative nurses' attitudes toward the electronic health record. J Perianesth Nurs 30(1): 23-32. DOI: 10.1016/j.jopan.2014.01.007. 